\title{
EXPLORING THE WHISTLEBLOWING INTENTION
}

\author{
Muhamad Naufal $^{\star}$
}

Accounting

Universitas Pendidikan Indonesia

Indonesia

Mnaufal30.mn@gmail.com

Alfira Sofia

Accounting

Universitas Pendidikan Indonesia

Indonesia

alfira.sofia@upi.edu

\section{Ida Farida Adi Prawira}

Accounting

Universitas Pendidikan Indonesia

Indonesia

Ida.farida@upi.edu

\section{R. Nelly Nur Apandi}

Accounting

Universitas Pendidikan Indonesia

Indonesia

Nellynurapandi.upi@gmail.com

*Corrosponding author’s Email: mnaufal30.mn@gmail.com

Peer-review under responsibility of 5th ${ }^{d}$ Asia International Conference 2019 Scientific Committee http://connectingasia.org/scientific-committee/ (C) 2019 Published by Readers Insight Publisher, lat 306 Savoy Residencia, Block 3 F11/1,44000 Islamabad. Pakistan, editor@readersinsight.net 


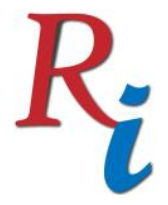

Asia Proceedings of Social Sciences

(APSS)

www.readersinsight.net/APSS

\section{A b s t r a c t}

This study's goal is to understand how individual and situational factors influencing the employee's psychological condition, which can impact the decision in conducting whistleblowing. This research type is descriptive qualitative. This study sample was the senior year students in the city of Bandung, Indonesia, who were undergoing the internship process with the purposive sampling sample collection technique. This research shows that employee sights materiality and advantages by doing the whistleblowing. Even if their whistleblowing result is not a success and gets the consequences, but they believe that they had done something right by doing the whistleblowing because of their moral responsibility. Through this research, organizations can get a new perspective in preparing a whistleblowing system, culture, and atmosphere that is suitable for whistleblowers so that the company will be more protected from possible frauds. This study has limitations on the theory used in looking at aspects that affect individuals in conducting whistleblowing. This research can be developed by looking at other elements that are also related to determining an individual's intention in doing whistleblowing since human is a complex creature. Also, different participants in the research would give the possibility of different answers to this study.

\section{Rese a r ch H igh I ight s}

1. Participants believe that fraud is a wrong thing and will choose to report it. But the participant still considers the seriousness of the fraud. They will report it if only the fraud is severe and has a systemic impact.

2. Participants consider that being excluded or resigning from a company that commits fraud is better than receiving retaliation in the company because by breaking ties with the company, the moral responsibility assumed by the employee will be lost and can continue his work activities in other companies without pressure and revenge.

3. If the perpetrators of the frauds are partners who are in the same position, then the decision making will also involve other factors such as competition in the company. If the whistleblower has other interests besides saving the company, for example, a promotion, then that will increase the employee's intention to report a colleague who's committing fraud. 


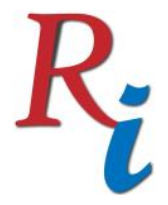

Asia Proceedings of Social Sciences

(APSS)

www.readersinsight.net/APSS

\section{Research Objectives}

Ethical violations that often found in an organization is a fraud. Fraud must be controlled by doing fraud prevention and fraud detection. An organization commonly used a whistleblowing system as a tool in managing fraud. Whistleblowing system is an essential tool for an organization because, without it, fraud, misconduct, and failure may dominate an organization (Carver, 2010). But, in fact, whistleblowers often get revenge for what they did. Retaliated actions include organizational steps taken to undermine the complaints process, reporter isolation, defamation of character, make difficulties or embarrass the reporter, exclusions from meetings, removal of bonuses, and other forms of discrimination or harassment (Tuanakotta, 2010).

Humans have different, traits, personalities, and characteristics, one to another that make individual is unique. This uniqueness can be the subject of research whether they will act the same according to their character in conducting whistleblowing. The purpose of this research is to understand how individual and situational factors can influence employee intention, which can affect the decision to do whistleblowing. Previous studies have only focused on whether several factors influence whistleblowing intentions, so this research is essential to be done to get a comprehensive understanding of how these factors affect employee whistleblowing intentions.

\section{Methodology}

This study uses a descriptive qualitative method to get a deeper understanding of the research conducted by analyzing text stated data (Raco, 2010). This research uses purposive sampling to collect the sample and limited to specific types of people who can provide the desired information (Sekaran, 2003), and it was obtained from senior year students in Bandung, Indonesia, who experienced an internship. These resource persons were chosen, assuming they have experience and insight in working in a company. The data collection techniques used were interviews and documentation. In this study, the model used to analyze data is the Miles and Huberman's. The activities in qualitative data analysis were carried out interactively and continuously until the data reached its saturation point. In data analysis, there are data reduction, data presentation, and data conclusion-verification (Miles and Huberman, A. 


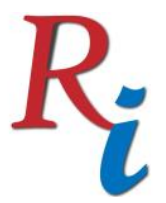

\section{Asia Proceedings of Social Sciences}

(APSS)

www.readersinsight.net/APSS

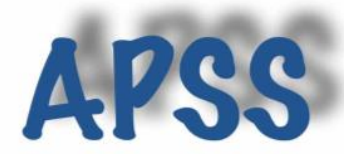

Michael Saldana, 2014). After the interview is done, the transcribed interview will be summarized, and only the relevant answer will be selected by using theme analysis. In this research, source triangulation and theory triangulation will be used. Source triangulation is used to test the credibility of the data carried out by examining data that has been obtained through several sources (Denzin, 1978), whereas the theories triangulation is the use of various perspectives to interpret a data set (Guion, 2002).

\section{Results}

The participants believe that fraud is a wrong thing and will choose to report it. They will report it if the fraud is severe and has a systemic impact. Conversely, if they felt that fraud has little effect and is not repeated, participants will choose to leave it alone.

Discussing protection, participants said that whistleblower protection provided by the company would increase their confidence to do whistleblowing. The reason is that the report they submitted will be questioned, so they need someone else who can support or back them up when the report is being discussed. Also, the reporter's personality factor is involved in making this decision. But some participants also said that there is a possibility that the protection of the company did not affect their intentions in conducting whistleblowing. The reason is that reporting fraud is a moral responsibility that they have so that any fraud that occurs must be reported.

Whistleblowing's consequences will limit the individual's intention. The facts of revenge that spread in society also make employees will rethink when they will do the whistleblowing. Adverse reporting about whistleblowing has an impact on employees. Employees will feel afraid to do whistleblowing because, according to the participants, "fear" is an inherent nature possessed by humans.

\section{Findings}

Both individual and situational factors are affecting someone's intention whether to conduct whistleblowing. The factors are Attitude Towards Behavior, Subjective Norm, Perceived Behavior Control, Fraud Seriousness, Protection, Management Seriousness, Whistleblowing System, The Consequences, Status of Wrongdoers, and Retaliation. Since every individual is different from one another, each person has they own preference in conducting whistleblowing. 


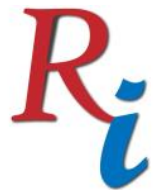

\section{Asia Proceedings of Social Sciences}

(APSS)

www.readersinsight.net/APSS

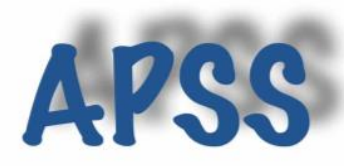

Also, the conditions faced are different so that this dilemma cannot be resolved absolutely. Whistleblowers will consider whistleblowing when the risks they face tend to be small, the power they have is greater, and the protection they receive makes them safe in doing whistleblowing.

\section{References}

Denzin, N.K., 1978. Sociological Methods: A Sourcebook. McGraw Hill, New York.

Guion, L.A., 2002. Triangulation : Establishing the Validity of Qualitative Studies 1. Dep.

Fam. Youth Community Sci. 1-3.

Miles, M.B., Huberman, A. Michael Saldana, J., 2014. Qualitative Data Analysis, 3rd ed.

Thousand Oaks.

Raco, J.R., 2010. Metode Penelitian Kualitatif. Grasindo, Jakarta.

Sekaran, U., 2003. Research Methods For Business: A Skill-Building Approach, Fourth. ed. John Wiley \& Sons, Inc.

Author's Biography

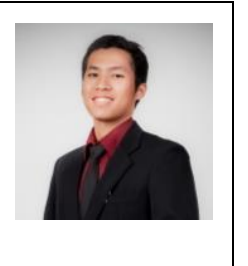

\section{Muhamad Naufal}

Senior year student in Universitas Pendidikan Indonesia who's majoring in Accounting. Interested in economy, finance, and accounting field especially auditing and tax.

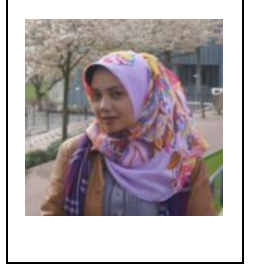

Alfria Sofia, S.T, M.M.,

Academics at the Universitas Pendidikan Indonesia (UPI) and researchers with major studies in finance and local governance. She has completed her undergraduate, master's and doctoral studies at the Bandung Institute of Technology with Management Science as a field taken at her Doctoral level. She currently serves as Project Manager at the UPI Accounting Development Center (PPA). 


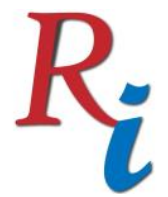

\section{Asia Proceedings of Social Sciences}

(APSS)

www.readersinsight.net/APSS
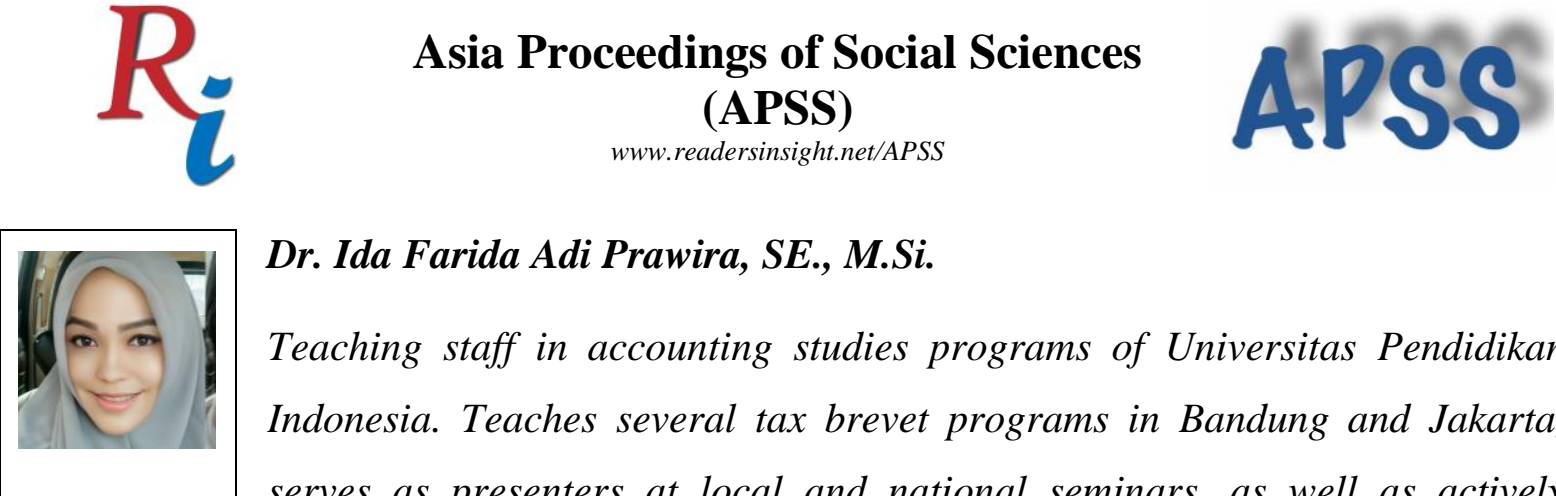

Dr. Ida Farida Adi Prawira, SE., M.Si.

Teaching staff in accounting studies programs of Universitas Pendidikan Indonesia. Teaches several tax brevet programs in Bandung and Jakarta, serves as presenters at local and national seminars, as well as actively providing assistance in solving tax problems in several individual and corporate taxpayers. Active in conducting research and actively writing research articles in national and international journals. Began her study at the Educational Company Administration Expert at Padjajaran University and then continued his existence program at STIE Indonesia Pembangunan. She holds a master of science degree and a doctorate degree at Padjadjaran University.

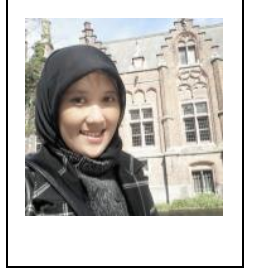

\section{R Nelly Nur Apandi,SE.,MSi.AK}

Academics in the accounting studies program at Universitas Pendidikan Indonesia, currently pursuing a doctoral degree at Universitas Indonesia. Active in research in the field of auditing and the public sector and is an auditor at Agus widarsono CPA Firm 